\title{
A MODEL TO EXPLAIN HIGH VALUES OF pH IN AN ALKALI SODIC SOIL
}

\author{
José Guerrero-Alves ${ }^{1 *}$; Ildefonso Pla-Sentís²; Rafael Camacho \\ ${ }^{1}$ Center for Research and Extension of Soils and Waters (CIESA), University "Rómulo Gallegos", San Juan de los \\ Morros 2301, Guárico-Venezuela. \\ ${ }^{2}$ Edafology Institute, University Central of Venezuela, Maracay-Venezuela. \\ ${ }^{*}$ Corresponding author <joseguer@cantv.net>
}

\begin{abstract}
For alkali sodic soils $(\mathrm{pH}>8.5)$, the "hydrolysis of exchangeable sodium" has been used as a possible explanation for the alkalinity production and rise in $\mathrm{pH}$ of these soils. As an alternative to this hypothesis, a model was developed to simulate and to explain that the alkalinity production and rise in $\mathrm{pH}$ is possible in a soil that accumulates alkaline sodium salts and $\mathrm{CaCO}_{3}$. Several simulations were performed by using different combinations of $\mathrm{CO}_{2}$ partial pressures $(P)$, presence or absence of $\mathrm{MgCO}_{3}$, along with experimental values of exchangeable sodium percentage (ESP) and ion concentrations in saturation extracts from an alkali sodic soil (named Pantanal). A hypothetical system with similar conditions to the Pantanal soil but with a Gapon selectivity coefficient (KG) of $0.01475\left(\mathrm{mmol} \mathrm{L}^{-1}\right)^{-1 / 2}$ was also considered. Good agreement was obtained between experimental and predicted values for $\mathrm{pH}$ and ion concentrations in the soil solution when the model (without $\mathrm{MgCO}_{3}$ ) was applied to the Pantanal soil. However, $\mathrm{KG}$ values calculated for the Pantanal soil were generally higher than $0.01475\left(\mathrm{mmol} \mathrm{L}^{-1}\right)^{-1 / 2}$. Moreover, high $\mathrm{pH}$ values and elevated ionic strength were obtained when a KG of 0.01475 (mmol L-1 $)^{-1 / 2}$ was used at high ESP (similar to those found in the Pantanal soil). KG values obtained for the Pantanal soil and the results obtained in the simulation of the hypothetical system are suggesting that a value higher than $0.01475\left(\mathrm{mmol} \mathrm{L}^{-1}\right)^{-1 / 2}$ should be used to adequately simulate the behavior of the Pantanal soil at low ionic strength and high ESP values.
\end{abstract}

Key words: Gapon selectivity coefficients, calcium carbonate, sodium bicarbonate, alkaline hydrolysis

\section{MODELO PARA EXPLICAR VALORES ELEVADOS DE pH EM UM SOLO SÓDICO ALCALINO}

\begin{abstract}
RESUMO: Em solos alcalino sódicos ( $\mathrm{pH}>8,5)$, a "hidrólise de sódio trocável" tem sido usada como uma possível explicação para a produção de álcali e elevação do pH nestes solos. Como uma alternativa a essa hipótese, um modelo foi desenvolvido para simular e explicar que a produção de álcali e elevação do pH é possível num solo que acumula sais alcalinos de sódio e $\mathrm{CaCO}_{3}$. Várias simulações foram feitas fazendo uso de diferentes combinações da pressão parcial de $\mathrm{CO}_{2}(P)$, presença ou ausência de $\mathrm{MgCO}_{3}$, com valores experimentais da porcentagem de sódio trocável (ESP) e concentrações de íons em extratos de saturação de um solo sódico alcalino (chamado Pantanal). Um sistema hipotético com condições similars ao solo Pantanal mas com um coeficiente de selectividade de Gapon (KG) de 0,01475 (mmol L-1 $)^{-1 / 2}$ foi, também, considerado. Boa concordância foi obtida entre os valores experimentais e os predezidos para $\circ \mathrm{pH}$ e concentração de íons na solução do solo quando o modelo (sem $\mathrm{MgCO}_{3}$ ) foi aplicado ao solo Pantanal. Porém, valores de KG calculados para o solo Pantanal estiveram muito acima de $0,01475\left(\mathrm{mmol} \mathrm{L}^{-1}\right)^{-1 / 2}$. Além disso, elevados valores de $\mathrm{pH}$ e da força iónica foram obtidos quando o $\mathrm{KG}$ de $0,01475\left(\mathrm{mmol} \mathrm{L}^{-1}\right)^{-1 / 2}$ foi usado a altos ESP. Valores de KG obtidos para o solo Pantanal e os resultados achados na simulação do sistema hipotético sugerem que um valor maior de $0,01475\left(\mathrm{mmol} \mathrm{L}^{-1}\right)^{-1 / 2}$ poderia ser empregado adequadamente para simular o comportamento do solo Pantanal a baixa força iônica e altos valores de ESP.

Palavras-chave: coeficiente de selectividade de Gapon, carbonato de cálcio, sais alcalinos de sódio, porcentagem de sódio trocável
\end{abstract}

\section{INTRODUCTION}

For alkali sodic soils $(\mathrm{pH}>8.5)$ the hydrolysis of exchangeable sodium has been used as a possible explanation for the alkalinity production and rise in $\mathrm{pH}$. The reaction:

$\mathrm{NaX}+\mathrm{H}_{2} \mathrm{O} \rightarrow \mathrm{HX}+\mathrm{Na}^{+}+\mathrm{OH}^{-}$

could be used to define the "hydrolysis of exchangeable sodium" (U.S. Salinity Laboratory Staff, 1954; Mashhady \& Rowell, 1978). After an increase in the exchangeable
$\mathrm{Na}$, subsequent dilution of the soil solution by rainwater or irrigation would cause desorption and hydrolysis of the weakly adsorbed $\mathrm{Na}$ with a rise in $\mathrm{pH}$ (Brown \& Miller, 1971; Shainberg, 1973; Mashhady \& Rowell, 1978). Reaction (1) can, however be split in two parts:

$$
\mathrm{H}_{2} \mathrm{O} \rightarrow \mathrm{H}^{+}+\mathrm{OH}^{-}
$$

$\mathrm{NaX}+\mathrm{H}^{+} \rightarrow \mathrm{HX}+\mathrm{Na}^{+}$

where (2) and (3) respectively define the water selfprotolysis and the sodium exchange by protons. 
In alkali sodic soils, the production of " $\mathrm{H}^{+*}$, as suggested by reaction 2 , must be strongly suppressed and, consequently, monovalent hydrogen cannot compete with the sodium ion for exchange sites. Under these conditions, the presence of "protonated clays" (HX) would not be possible in these soils and, therefore, both $\mathrm{NaOH}$ and alkalinity production cannot be explained by reaction (1).

In alkali sodic soils, at relatively low ionic strength, high $\mathrm{pH}$ values may be related to the accumulation of sodium bicarbonates and carbonates, which are soluble salts capable of undergoing alkaline hydrolysis (Kovda \& Samoilova, 1969; Szabolcs, 1969; Cruz-Romero \& Coleman, 1975; Gupta et al., 1985; Szabolcs, 1987; Gupta \& Abrol, 1990; Guerrero-Alves, 1998). Other evidences also point out that the presence of precipitated $\mathrm{CaCO}_{3}$ and $\mathrm{MgCO}_{3}$ are determining high values of $\mathrm{pH}$ in alkali sodic soils (Cruz-Romero \& Coleman, 1975; Pla-Sentís, 1985; Gupta \& Abrol, 1990; Guerrero-Alves, 1998). For these reasons, reaction (1) cannot explain the high $\mathrm{pH}$ values in alkali sodic soils.

The purpose of this work was to find a model to simulate and to explain the alkalinity production and rise in $\mathrm{pH}$ in soils that accumulate alkaline sodium salts jointly with precipitated carbonates of divalent ions $\left(\mathrm{CaCO}_{3}\right.$ and $\mathrm{MgCO}_{3}$ ) to relatively low ionic strength. Exchange of $\mathrm{Ca}-$ $\mathrm{Mg}-\mathrm{Na}$ ions was considered. Other anions such as chlorides and sulfates were also included in the model to have conditions closer to real alkali sodic soils. The procedure of Nakayama (1970) was modified to establish a computational routine.

\section{Development of the model}

The balance of charges in solution for a system composed by sodium carbonates and bicarbonates; an exchanger limited to $\mathrm{Ca}-\mathrm{Mg}-\mathrm{Na}$ ions; $\mathrm{CaCO}_{3} ; \mathrm{MgCO}_{3}$; an external $\mathrm{CO}_{2}$ source; and chlorides and sulfates; can be given by:

$\left[\mathrm{H}^{+}\right]+\left[\mathrm{Na}^{+}\right]+2\left[\mathrm{Ca}^{2+}\right]+2\left[\mathrm{Mg}^{2+}\right]=\left[\mathrm{HCO}_{3}^{-}\right]+2\left[\mathrm{CO}_{3}^{2-}\right]+$

$\left[\mathrm{OH}^{-}\right]+\left[\mathrm{Cl}^{-}\right]+2\left[\mathrm{SO}_{4}^{2-}\right]$

where the brackets for chemical species [ ] denote molar concentration in aqueous solution.

Concentrations of $\mathrm{H}^{+}, \mathrm{Ca}^{2+}, \mathrm{Mg}^{2+}, \mathrm{HCO}_{3} ; \mathrm{CO}_{3}^{2-}$ and $\mathrm{OH}^{-}$are regulated by the constants of dissociation, ionization or precipitation, which have been adapted from Nakayama (1970) [except equation 9].

$$
\begin{aligned}
\mathrm{K}_{1 \mathrm{~A}} & =\frac{\left[\mathrm{H}^{+}\right] \cdot \mathrm{r}_{1} \cdot\left[\mathrm{HCO}_{3}^{-}\right] \cdot \mathrm{r}_{3}}{\left(\mathrm{H}_{2} \mathrm{CO}_{3}\right)} \\
\mathrm{K}_{2 \mathrm{~A}} & =\frac{\left[\mathrm{H}^{+}\right] \cdot \mathrm{r}_{1} \cdot\left[\mathrm{CO}_{3}^{2-}\right] \cdot \mathrm{r}_{4}}{\left[\mathrm{HCO}_{3}^{-}\right] \cdot \mathrm{r}_{3}} \\
\mathrm{~K}_{\mathrm{W}} & =\left[\mathrm{H}^{+}\right] \cdot \mathrm{r}_{1} \cdot\left[\mathrm{OH}^{-}\right] \cdot \mathrm{r}_{2}
\end{aligned}
$$

$$
\begin{aligned}
& \mathrm{K}_{\mathrm{S}}=\left[\mathrm{Ca}^{2+}\right] \cdot \mathrm{r}_{5} \cdot\left[\mathrm{CO}_{3}^{2-}\right] \cdot \mathrm{r}_{4} \\
& \mathrm{~K}_{\mathrm{S} 2}=\left[\mathrm{Mg}^{2+}\right] \cdot \mathrm{r}_{9} \cdot\left[\mathrm{CO}_{3}^{2-}\right] \cdot \mathrm{r}_{4} \\
& \left(\mathrm{H}_{2} \mathrm{CO}_{3}\right)=\mathrm{k} \cdot \mathrm{P} \\
& \mathrm{k}=0.0344-0.0084 . \mathrm{I}
\end{aligned}
$$

where $\mathrm{K}_{1 \mathrm{~A}}$ and $\mathrm{K}_{2 \mathrm{~A}}$ respectively define the first and second constants of $\mathrm{H}_{2} \mathrm{CO}_{3}$ ionization; $\mathrm{KW}=$ water self-protolysis constant; $\mathrm{K}_{\mathrm{S}}=$ solubility product constant of $\mathrm{CaCO}_{3} ; \mathrm{K}_{\mathrm{S} 2}=$ solubility product constant of $\mathrm{MgCO}_{3}$; $\mathrm{k}=$ Henry's law constant for the solubility of $\mathrm{CO}_{2} ; P=$ partial pressure of $\mathrm{CO}_{2}$; and $\mathrm{I}=$ ionic strength of the resulting solution. $\mathrm{r}_{1}, \mathrm{r}_{2}$, $r_{3}, r_{4}, r_{5}$ and $r_{9}$ are respectively the activity coefficients for $\mathrm{H}^{+}, \mathrm{OH}^{-}, \mathrm{HCO}_{3}, \mathrm{CO}_{3}{ }^{2-}, \mathrm{Ca}^{2+}$ and $\mathrm{Mg}^{2+}$. The activity coefficients for $\mathrm{Na}^{+}, \mathrm{Cl}^{-}$and $\mathrm{SO}_{4}^{2-}$ ions, not explicitly included in equations from (4) to (11) but necessary in the calculations, are respectively $r_{6}, r_{7}$ and $r_{8}$. Brackets for chemical species ( ) define the activities in solution.

The Ca-Na exchange reaction, as initially proposed by Gapon (Bohn et al., 1979), has the form:

$\mathrm{Ca}_{1 / 2} \mathrm{X}+\mathrm{Na}^{+} \longrightarrow \mathrm{NaX}+1 / 2 \mathrm{Ca}^{2+}$

Considering for the magnesium ion an analogue behavior to the calcium ion (Porta et al., 1999), the Gapon selectivity coefficient (KG) can be calculated as follows:

$K G=\frac{[\mathrm{NaX}] \cdot\left[\mathrm{Ca}^{2+}+\mathrm{Mg}^{2+}\right]^{1 / 2}}{\left[\mathrm{Ca}_{1 / 2} \mathrm{X}+\mathrm{Mg}_{1 / 2} \mathrm{X}\right] \cdot\left[\mathrm{Na}^{+}\right]}$

where the concentrations of exchangeable cations, [NaX] or $\left[\mathrm{Ca}_{1 / 2} \mathrm{X}+\mathrm{Mg}_{1 / 2} \mathrm{X}\right]$, are expressed on $\mathrm{cmol}(+) \mathrm{kg}^{-1}$, and the soluble cation concentrations are expressed as mol $\mathrm{L}^{-1}$. From equation (13), it follows that sodium concentration in the solution can be estimated from the equivalent fractions of sodium on the exchanger $\left(\mathrm{E}_{\mathrm{Na}}\right),\left[\mathrm{Ca}^{2+}+\mathrm{Mg}^{2+}\right]$ and $K G$ as follows:

$$
\left[\mathrm{Na}^{+}\right]=\frac{\mathrm{E}_{\mathrm{Na}} \cdot\left[\mathrm{Ca}^{2+}+\mathrm{Mg}^{2+}\right]^{1 / 2}}{\left(1-\mathrm{E}_{\mathrm{Na}}\right) \cdot \mathrm{KG}}
$$

Combining equations (5), (6), (7), (8) and (9) with equations (10), (11), (14) and (4) results:

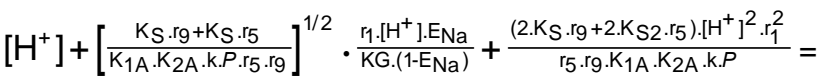

$$
\begin{aligned}
& \frac{\mathrm{K}_{1 A} \cdot \mathrm{K} \cdot \mathrm{P}}{\left[\mathrm{H}^{+}\right] \cdot \mathrm{r}_{1} \cdot r_{3}}+\frac{2 \cdot \mathrm{K}_{1 A} \cdot \mathrm{K}_{2} \mathrm{~A} \cdot \mathrm{K} \cdot \mathrm{P}}{\left[\mathrm{H}^{+}\right]^{2} \cdot \mathrm{r}_{1}^{2} \cdot \mathrm{r}_{4}}+\frac{\mathrm{KW}_{\mathrm{W}}}{\left.\mathrm{r}_{1} \cdot \mathrm{r}_{2} \cdot \mathrm{H}^{+}\right]}+\left[\mathrm{Cl}^{-}\right]+2\left[\mathrm{SO}_{4}^{2-}\right]
\end{aligned}
$$

Rearranging equation (15) and expressing $\mathrm{H}^{+}$as hydrogen ion activity $\left(\mathrm{H}^{+}\right)$, the equation becomes:

$\mathrm{F} 1 \cdot\left(\mathrm{H}^{+}\right)^{4}+\mathrm{F} 2 \cdot\left(\mathrm{H}^{+}\right)^{3}+\mathrm{F} 3 \cdot\left(\mathrm{H}^{+}\right)^{2}+\mathrm{F} 4\left(\mathrm{H}^{+}\right)+\mathrm{F} 5=0$

where:

$\mathrm{F} 1=\frac{2 \cdot \mathrm{K}_{\mathrm{s}} \cdot \mathrm{r}_{9}+2 \cdot \mathrm{K}_{\mathrm{S} 2} \cdot \mathrm{r}_{5}}{\mathrm{~K}_{1 \mathrm{~A}} \cdot \mathrm{K}_{2 \mathrm{~A}} \cdot \mathrm{k} \cdot P \cdot \mathrm{r}_{1}^{2} \cdot \mathrm{r}_{5} \cdot \mathrm{r}_{9}}$ 
$\mathrm{F} 2=\frac{1}{\mathrm{r}_{1}^{3}}+\left[\frac{\mathrm{K}_{\mathrm{S}} \cdot \mathrm{r}_{9}+\mathrm{K}_{\mathrm{S} 2} \cdot \mathrm{r}_{5}}{\mathrm{~K}_{1} \mathrm{~A} \cdot \mathrm{K}_{2 \mathrm{~A}} \cdot \mathrm{K} \cdot \mathrm{P} \cdot \mathrm{r}_{5} \cdot \mathrm{r}_{9}}\right]^{1 / 2} \cdot \frac{\mathrm{E}_{\mathrm{Na}}}{\mathrm{KG} \cdot\left(1-\mathrm{E}_{\mathrm{Na}}\right) \cdot \mathrm{r}_{1}^{2}}$

$\mathrm{F} 3=-\frac{\left(\mathrm{Cl}^{-}\right)}{\mathrm{r}_{1}^{2} \cdot \mathrm{r}_{7}}-\frac{2\left(\mathrm{SO}_{4}^{2-}\right)}{\mathrm{r}_{1}^{2} \cdot \mathrm{r}_{8}}$

$\mathrm{F} 4=\frac{\mathrm{K}_{1 \mathrm{~A}} \cdot \mathrm{k} \cdot P}{\mathrm{r}_{1}^{2} \cdot \mathrm{r}_{3}}-\frac{\mathrm{K}_{\mathrm{W}}}{\mathrm{r}_{1}^{2} \cdot \mathrm{r}_{2}}$

$\mathrm{F} 5=-\frac{2 \cdot \mathrm{K}_{1 \mathrm{~A}} \cdot \mathrm{K}_{2 \mathrm{~A}} \cdot \mathrm{k} \cdot P}{\mathrm{r}_{1}^{2} \cdot \mathrm{r}_{4}}$

The preceding procedure used to obtain polynomial coefficients of equation (16) can be also employed to obtain an equivalent expression to equation 15 but considering that precipitated $\mathrm{MgCO}_{3}$ does not control the presence of magnesium in solution. To facilitate the resolution of this equivalent expression it is necessary to assume that $\left[\mathrm{Mg}^{2+}\right]$ is much higher as compared to $\left[\mathrm{Ca}^{2+}\right]\left(\left[\mathrm{Mg}^{2+}\right] \gg>>\left[\mathrm{Ca}^{2+}\right]\right)$. In consequence, it can be shown that F1, F2 and F3, new coefficients of equation (16), correspond to the following expressions:

$\mathrm{F} 1=\frac{2 \cdot \mathrm{K}_{\mathrm{S}}}{\mathrm{K}_{1 \mathrm{~A}} \cdot \mathrm{K}_{2 \mathrm{~A}} \cdot \mathrm{k} \cdot P \cdot \mathrm{r}_{1}^{2} \cdot \mathrm{r}_{5}}$

$\mathrm{F} 2=\frac{1}{\mathrm{r}_{1}^{3}}$

$\mathrm{F} 3=\left[\frac{\left(\mathrm{Mg}^{2+}\right)}{\mathrm{r}_{9}}\right]^{1 / 2} \cdot \frac{\mathrm{E}_{\mathrm{Na}}}{\mathrm{KG} \cdot\left(1-\mathrm{E}_{\mathrm{Na}}\right) \cdot \mathrm{r}_{1}^{2}}+\frac{2\left(\mathrm{Mg}^{2+}\right)}{\mathrm{r}_{1}^{2} \cdot \mathrm{r}_{9}}-\frac{\left(\mathrm{Cl}^{-}\right)}{\mathrm{r}_{1}^{2} \cdot \mathrm{r}_{7}}-\frac{2\left(\mathrm{SO}_{4}^{2-}\right)}{\mathrm{r}_{1}^{2} \cdot \mathrm{r}_{8}}$

In this case, F4 and F5 do not change and they are respectively equal to equations (20) and (21).

\section{MATERIAL AND METHODS}

In order to calculate $\mathrm{pH}$, concentrations of all chemical species in aqueous solution and KG (when necessary), the models (equations from 17 to 21 or from 20 to 24) were translated into the BASIC language and operated using a digital computer system. The programs (when necessary) used different partial pressures of $\mathrm{CO}_{2}$ $(P)$.

In the first and the second simulations, a natural system with accumulation of alkaline sodic salts, $\mathrm{CaCO}_{3}$, $\mathrm{MgCO}_{3}$ (only $\mathrm{CaCO}_{3}$ in the second simulation) and the partial atmospheric pressure of $\mathrm{CO}_{2}(P)\left[0.35 \times 10^{-4} \mathrm{MPa}\right]$ was assumed. Both programs used experimental values of ESP and, [Cl], [ $\left.\mathrm{SO}_{4}{ }^{2}\right], \mathrm{Mg}^{2+}$ (assumed as [Ca+Mg] in the second simulation and predicted in the first simulation) and $\left[\mathrm{Na}^{+}\right]$in the saturation extracts, from an alkali sodic soil named Pantanal (Table 1). These values were employed to predict $\mathrm{pH}, \mathrm{KG}$, and $\left[\mathrm{CO}_{3}^{2}\right]$, $\left[\mathrm{HCO}_{3}{ }^{-}\right]$, $\left[\mathrm{Ca}^{2+}\right]$ and $\left[\mathrm{Mg}^{2+}\right]$ (only in the first simulation) in the soil solution. Equations from (17) to (21) and from (20) to (24) were respectively used in the first and the second simulations. Results are shown in Tables 2 and 3.
The same experimental values of ESP and ion concentrations used in the second simulation were also employed in a third simulation. However, the partial pressures of $\mathrm{CO}_{2}$ were additionally varied to generate the $\mathrm{pH}$ values in the saturation pastes of the Pantanal soil (Table 1). Results of third simulation are shown in Table 4.

A system composed by alkaline sodium salts, $\mathrm{CaCO}_{3}$ (without $\mathrm{MgCO}_{3}$ ) and an exchanger of ions (Ca$\mathrm{Mg}-\mathrm{Na}$ ) with an hypothetical KG of $0.01475\left(\mathrm{mmol} \mathrm{L}^{-1}\right)^{-1 / 2}$ [U.S. Salinity Laboratory Staff, 1954], was also simulated by using equations (20) to (24). The $\mathrm{pH}$ and concentrations of all chemical species in solution were generated at $10 \%$ ESP (exchangeable sodium percentage) intervals, from 10 up to $90 \%$. Chloride, sulfate and magnesium concentrations of respectively 4 , 1 and $1 \mathrm{mmol}_{\mathrm{ct}} \mathrm{L}^{-1}$ (similar to those found in the Pantanal soil) were considered (Table 5). To study the effect of the ionic strength and to maintain the validity of the approximation $\left[\mathrm{Mg}^{2+}\right] \gg>>\left[\mathrm{Ca}^{2+}\right]$ (necessary to operate the model), the sulfate concentration was increased in 2 $\mathrm{mmol}_{\mathrm{ct}^{-1}} \mathrm{~L}^{-1}$ for each 10\% ESP intervals from a initial value of $2 \mathrm{mmol}_{\mathrm{c}^{+}} \mathrm{L}^{-1}$ (Table 6).

In all simulations, the models use an autoconsistent iterative method, similar to the one of Nakayama (1970), which compare consecutive values of the ionic strength and hydrogen ion activity $\left(\mathrm{H}^{+}\right)$; the latter comparison is "nested" into the ionic strength iterations. At the first stage of the computational process, a reasonable initial "guess" of the ionic strength was necessary for estimating the ionic activity coefficients, which were calculated according to the extended DebyeHückel equation (Peters et al., 1974). This step was necessary because the ionic concentrations were unknown at this stage (Nakayama, 1970).

The initial activity coefficients, in combination with the equilibrium constants, KG, ESP, $P$, and chloride, along with sulfate and magnesium (when necessary) concentrations, were used to compute the coefficients (equations from 17 to 21 or from 20 to 24 ) of the $4^{\text {th }}$ grade polynomial (equation 16). To solve the $4^{\text {th }}$ grade polynomial equation for $\left(\mathrm{H}^{+}\right)$, the Newton-Raphson iterative procedure was used, which also needs a reasonable initial "guess" of $\mathrm{pH}$. This iterative procedure was continued until two similar consecutive values of $\left(\mathrm{H}^{+}\right)$ [differences $<10^{-30}$ ] were obtained. The first $\left(\mathrm{H}^{+}\right)$value (first iteration for ionic strength) and the necessary set of equations (equations from 5 to 11 and 14) were then used to compute the cation and anion concentrations and, consequently, a new ionic strength value was obtained. This new ionic strength was used in the second iteration to improve the activity coefficients. The iterative procedure for the ionic strength was continued until obtaining two close successive values (differences $<10^{-21}$ ).

In the first, second and third simulations, in order to find a KG value compatible to both, the concentrations of exchangeable ions as well as soluble ions, the ionic strength iterations were nested in a computational 
Table 1 - Experimental values* of $\mathrm{pH}$, exchangeable sodium percentage (ESP), soluble ions and precipitated carbonates (Carbp) of the Pantanal soil, determined at $0.1 \mathrm{~m}$ depth intervals.

\begin{tabular}{|c|c|c|c|c|c|c|c|c|}
\hline Depth & $\mathrm{pH}$ & $\mathrm{ESP}$ & $\mathrm{Cl}^{-}$ & $\mathrm{SO}_{4}{ }^{2-}$ & $\mathrm{Na}^{+}$ & $\mathrm{Ca}+\mathrm{Mg}$ & $\mathrm{HCO}_{3}+\mathrm{CO}_{3}{ }^{2-}$ & Carbp \\
\hline -- m -- & & $\%$ & ----- & - & $\mathrm{mmol}$ & 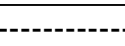 & 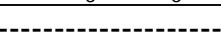 & $\mathrm{mmol} \mathrm{kg}^{-1}$ \\
\hline $0.0-0.1$ & 5.13 & 10.18 & 1.80 & 2.73 & 6.11 & 0.69 & 1.28 & 5.3 \\
\hline $0.1-0.2$ & 8.14 & 41.59 & 9.00 & 4.64 & 23.88 & 1.48 & 9.24 & 6.5 \\
\hline $0.2-0.3$ & 8.88 & 56.24 & 3.70 & 2.73 & 16.79 & 0.99 & 9.84 & 27.2 \\
\hline $0.3-0.4$ & 9.12 & 58.44 & 5.20 & 2.38 & 25.36 & 1.28 & 16.52 & 28.3 \\
\hline $0.4-0.5$ & 9.28 & 77.56 & 3.00 & 0.81 & 18.62 & 0.99 & 13.16 & 189.8 \\
\hline $0.5-0.6$ & 9.36 & 88.51 & 3.60 & 0.78 & 18.31 & 0.69 & 13.00 & 115.4 \\
\hline $0.6-0.7$ & 9.35 & 78.73 & 5.20 & 1.06 & 24.49 & 0.59 & 16.64 & 93.8 \\
\hline $0.7-0.8$ & 9.40 & 73.06 & 5.70 & 0.89 & 24.27 & 0.89 & 15.24 & 19.0 \\
\hline $0.8-0.9$ & 9.35 & 75.35 & 5.30 & 0.96 & 23.27 & 0.59 & 14.82 & 39.1 \\
\hline $0.9-1.0$ & 9.38 & 74.35 & 4.50 & 0.99 & 21.10 & 0.59 & 14.20 & 31.8 \\
\hline $1.0-1.1$ & 9.31 & 73.08 & 4.60 & 0.91 & 16.62 & 0.49 & 9.28 & 6.7 \\
\hline $1.1-1.2$ & 9.18 & 79.30 & 3.60 & 0.96 & 9.53 & 0.49 & 4.04 & 5.8 \\
\hline $1.2-1.3$ & 9.50 & 79.82 & 2.80 & 1.35 & 16.27 & 0.30 & 11.96 & 308.9 \\
\hline $1.3-1.4$ & 9.47 & 79.10 & 2.80 & 0.91 & 15.83 & 0.49 & 11.64 & 133.7 \\
\hline $1.4-1.5$ & 9.46 & 81.60 & 3.00 & 0.99 & 14.31 & 0.39 & 10.18 & 44.6 \\
\hline $1.5-1.6$ & 9.42 & 77.38 & 3.20 & 0.78 & 11.92 & 0.39 & 7.84 & 11.3 \\
\hline $1.6-1.7$ & 9.51 & 72.90 & 3.20 & 1.06 & 16.79 & 0.30 & 12.48 & 338.4 \\
\hline $1.7-1.8$ & 9.53 & 72.39 & 3.60 & 0.91 & 17.88 & 0.49 & 13.40 & 245.8 \\
\hline $1.8-1.9$ & 9.51 & 72.72 & 3.20 & 0.86 & 15.62 & 0.49 & 12.32 & 86.5 \\
\hline $1.9-2.0$ & 9.47 & 71.46 & 3.20 & 1.06 & 13.01 & 0.20 & 9.84 & 8.2 \\
\hline $2.0-2.1$ & 9.39 & 67.14 & 3.10 & 0.78 & 14.79 & 0.49 & 12.40 & 87.7 \\
\hline 2.1-2.2 & 9.37 & 65.44 & 3.10 & 0.71 & 14.18 & 0.39 & 11.92 & 72.0 \\
\hline 2.2-2.3 & 9.35 & 60.24 & 3.30 & 0.71 & 14.27 & 0.49 & 11.92 & 56.3 \\
\hline 2.3-2.4 & 9.38 & 68.49 & 3.10 & 0.78 & 14.09 & 0.39 & 12.28 & 92.7 \\
\hline $2.4-2.5$ & 9.41 & 68.55 & 3.30 & 0.65 & 15.49 & 0.39 & 11.40 & 118.9 \\
\hline
\end{tabular}

${ }^{*}$ Results are the average of three determinations.

routine, which departing from an initial $K G$ value $\left(<0.01475\left(\mathrm{mmol} \mathrm{L}^{-1}\right)^{-1 / 2}\right)$ gave different $K G$ values. These $K G$ values were changed until the last $K G$ value permitted to obtain $\left[\mathrm{Na}^{+}\right]$similar to the one in the saturation extracts.

The equilibrium constants (except $\mathrm{K}_{\mathrm{s} 2}$ ) used in equations $17,18,20,21$ and 22 were taken from Nakayama (1970). Their values were: $\mathrm{K}_{1 \mathrm{~A}}=4.34 \times 10^{-7}$, $\mathrm{K}_{2 \mathrm{~A}}=4.69 \times 10^{-11}, \mathrm{Kw}=1 \times 10^{-14}, \mathrm{Ks}=5.0 \times 10^{-9}$, and $\mathrm{k}=0.0344-$ $0.0084 . I$. The $K_{\mathrm{s} 2}$ value $\left(1 \times 10^{-5}\right)$ was obtained from Skoog \& West (1975).

Samples were collected from a pedon belonging to the Chaguaramas Series (Chaguaramas, Guárico State-Venezuela), 9'20'36" NL and 66 $16^{\circ}$ ' 40" WL. The pedon, named here as Pantanal soil, was classified as a Typic Natrustalf (Soil Survey Staff, 1998) and was sampled at $0.1 \mathrm{~m}$ depth intervals up to the $2.5 \mathrm{~m}$ depth. The twenty-five soil samples obtained were air dried and passed through a $2 \mathrm{~mm}$ sieve. The material $>2 \mathrm{~mm}$ was individually crushed to sizes $<2 \mathrm{~mm}$ and incorporated to the previously sieved soil less than $2 \mathrm{~mm}$, and then homogenized.

In every individually homogenized soil samples, the $\mathrm{pH}$ was measured in the saturation paste, and the extract was used for determination of $\mathrm{Ca}^{2+}+\mathrm{Mg}^{2+}, \mathrm{Na}^{+}$, $\mathrm{CO}_{3}^{2-}, \mathrm{HCO}_{3}^{-}, \mathrm{Cl}^{-}$and $\mathrm{SO}_{4}^{2-}$ (U.S. Salinity Laboratory Staff, 1954). As all extracts were dark colored, it was necessary to process them with the clarifying technique of Robbins (1989).

On the other hand, $100 \mathrm{~g}$ of the same twenty five processed soil samples were additionally crushed to sizes $<0.425 \mathrm{~mm}$ and homogenized. These samples were used for the determination of the cation exchange capacity (CEC) and ESP (U.S. Salinity Laboratory Staff, 1954). Calcium and magnesium carbonates were analyzed as described by Pla-Sentís (1969).

All determinations were carried out in triplicate and the experimental values shown in the Table 1 are the averages of these determinations.

\section{RESULTS AND DISCUSSION}

Results obtained by our model, assuming a soil that accumulates alkaline sodium salts, $\mathrm{CaCO}_{3}$ and $\mathrm{MgCO}_{3}$ (using equations from 17 to 21), show that the values of $\mathrm{pH}$ measured in the Pantanal soil were similar to the predicted ones (the differences were lower than $3 \%$ of measured data) to $0.5-2.5 \mathrm{~m}$ depth (Figure 1; Tables 1 and 2). However, predicted $\left[\mathrm{Mg}^{2+}\right]$ (Table 2) were 16 to 92 times higher than $[\mathrm{Ca}+\mathrm{Mg}]$ measured in saturation extracts at the same depth (Table 1). These results indicate that $\mathrm{MgCO}_{3}$ phase is not controlling the $\left[\mathrm{Mg}^{2+}\right]$ in the soil solution of the Pantanal soil. Precipitated 
Table 2 - Ion concentrations, $\mathrm{pH}$ and Gapon selectivity coefficients (KG) of the Pantanal soil, at 0.1 -m depth intervals, predicted by using the proposed model (equations from 17 to 21 ) and experimental data from Table $1\left(\mathrm{PCO}_{2}=0.35 \times 10^{-4}\right.$ $\mathrm{MPa})$.

\begin{tabular}{|c|c|c|c|c|c|c|c|}
\hline Depth & $\mathrm{Ca}^{2+}$ & $\mathrm{Mg}^{2+}$ & $\mathrm{HCO}_{3}^{-}$ & $\mathrm{CO}_{3}{ }^{2-}$ & $\mathrm{HCO}_{3}{ }^{-}+\mathrm{CO}_{3}{ }^{2-}$ & $\mathrm{pH}$ & $K G$ \\
\hline -- m -- & $-\cdots$ & - & $-\mathrm{mmo}$ & - & 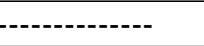 & & $\left(\mathrm{mmol} \mathrm{L}^{-1}\right)^{-1 / 2}$ \\
\hline $0.0-0.1$ & 0.01 & 22.16 & 16.62 & 7.09 & 23.71 & 9.42 & 0.06176 \\
\hline $0.1-0.2$ & 0.01 & 18.60 & 19.09 & 9.73 & 28.82 & 9.48 & 0.09096 \\
\hline $0.2-0.3$ & 0.01 & 17.86 & 18.89 & 9.30 & 28.19 & 9.48 & 0.22878 \\
\hline $0.3-0.4$ & 0.01 & 14.94 & 21.02 & 11.67 & 32.69 & 9.52 & 0.15161 \\
\hline $0.4-0.5$ & 0.01 & 15.66 & 20.03 & 10.41 & 30.44 & 9.50 & 0.51959 \\
\hline $0.5-0.6$ & 0.01 & 16.06 & 19.80 & 10.16 & 29.96 & 9.50 & 1.19251 \\
\hline $0.6-0.7$ & 0.01 & 14.62 & 21.11 & 11.71 & 32.82 & 9.52 & 0.40880 \\
\hline $0.7-0.8$ & 0.01 & 14.84 & 20.95 & 11.54 & 32.49 & 9.52 & 0.30444 \\
\hline $0.8-0.9$ & 0.01 & 15.05 & 20.74 & 11.29 & 32.03 & 9.51 & 0.36050 \\
\hline $0.9-1.0$ & 0.01 & 15.51 & 20.31 & 10.78 & 31.09 & 9.51 & 0.38268 \\
\hline $1.0-1.1$ & 0.01 & 17.36 & 19.04 & 9.40 & 28.44 & 9.48 & 0.48130 \\
\hline $1.1-1.2$ & 0.01 & 20.22 & 17.40 & 7.77 & 25.17 & 9.44 & 1.27864 \\
\hline 1.2-1.3 & 0.01 & 16.81 & 19.28 & 9.62 & 28.90 & 9.49 & 0.70506 \\
\hline $1.3-1.4$ & 0.01 & 16.75 & 19.26 & 9.58 & 28.84 & 9.49 & 0.69212 \\
\hline $1.4-1.5$ & 0.01 & 17.57 & 18.77 & 9.09 & 27.86 & 9.48 & 0.91875 \\
\hline $1.5-1.6$ & 0.01 & 18.67 & 18.13 & 8.45 & 26.58 & 9.46 & 0.87696 \\
\hline $1.6-1.7$ & 0.01 & 16.64 & 19.40 & 9.74 & 29.14 & 9.49 & 0.46222 \\
\hline 1.7-1.8 & 0.01 & 16.30 & 19.64 & 10.00 & 29.64 & 9.49 & 0.41880 \\
\hline $1.8-1.9$ & 0.01 & 17.02 & 19.12 & 9.44 & 28.56 & 9.48 & 0.49801 \\
\hline $1.9-2.0$ & 0.01 & 18.32 & 18.36 & 8.68 & 27.04 & 9.47 & 0.58264 \\
\hline $2.0-2.1$ & 0.01 & 17.29 & 18.93 & 9.24 & 28.17 & 9.48 & 0.40624 \\
\hline 2.1-2.2 & 0.01 & 17.52 & 18.78 & 9.08 & 27.86 & 9.48 & 0.39528 \\
\hline 2.2-2.3 & 0.01 & 17.58 & 18.75 & 9.06 & 27.81 & 9.47 & 0.31490 \\
\hline 2.3-2.4 & 0.01 & 17.60 & 18.74 & 9.04 & 27.78 & 9.47 & 0.45771 \\
\hline 2.4-2.5 & 0.01 & 17.01 & 19.10 & 9.42 & 28.52 & 9.48 & 0.41048 \\
\hline
\end{tabular}

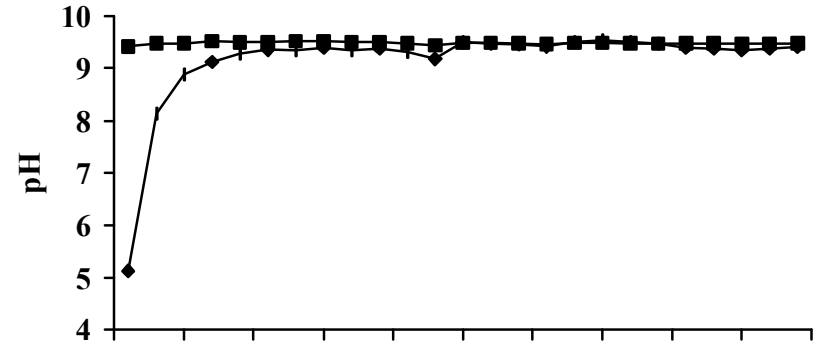

$\begin{array}{lllllllllllllll}0.00 & 0.25 & 0.50 & 0.75 & 1.00 & 1.25 & 1.50 & 1.75 & 2.00 & 2.25 & 2.50\end{array}$ DEPTH (m)

\section{$\rightarrow \mathrm{pH}(\mathrm{SP}) \rightarrow \mathrm{pH}(\mathrm{MOD})$}

Figure 1 - Experimental $\mathrm{pH}$ values measured in saturation paste (SP) and $\mathrm{pH}$ values predicted by using the proposed model (MOD) [equations from 17 to 21], at $0.1 \mathrm{~m}$ depth intervals, in the Pantanal soil.

carbonates in the Pantanal soil seem to be mainly composed by $\mathrm{CaCO}_{3}$, which was additionally corroborated by the analysis of precipitated salts (not reported here) in this soil (Guerrero-Alves, 1998).

Taking into account these previous results, a new model was used for the Pantanal soil, which excludes the presence of $\mathrm{MgCO}_{3}$ (using equations from 20 to 24) and employs $[\mathrm{Ca}+\mathrm{Mg}]$ as magnesium concentrations. The values of $\mathrm{pH}$ measured in the Pantanal soil were also similar to the predicted ones, except for the $0.0-0.2 \mathrm{~m}$ depth (Figure 2) where the differences were over $4 \%$. This can be due to the very low concentrations of precipitated calcium carbonates found at that depth (Table 1), or the assumption that the $\mathrm{CO}_{2}$ partial pressure is atmospheric $\left(0.35 \times 10^{-4} \mathrm{MPa}\right)$ is not very realistic for a saturation paste. On the other hand, this model seems to predict adequately $\left[\mathrm{HCO}_{3}\right]+\left[\mathrm{CO}_{3}{ }^{2}\right]$ in the saturation extracts, as is shown in Figure 3 . In $90 \%$ of the cases below $0.2 \mathrm{~m}$ depth, differences between experimental and predicted data (Tables 1 and 3, respectively) oscillated between 2 and $21 \%$ of experimental $\left[\mathrm{HCO}_{3}{ }^{-}\right]+\left[\mathrm{CO}_{3}{ }^{2-}\right]$; which are respectively representing differences between 0.3 and $2.6 \mathrm{mmol}_{\mathrm{ct}} \mathrm{L}^{-1}$ in predicted $\left[\mathrm{HCO}_{3}^{-}\right]+\left[\mathrm{CO}_{3}^{2-}\right]$.

In relation to divalent ions below $0.2 \mathrm{~m}$ depth (Table 3), predicted values of $\left[\mathrm{Ca}^{2+}\right]$ (between 0.01 and $0.08 \mathrm{mmol}_{\mathrm{ct}^{+}} \mathrm{L}^{-1}$ ) correspond around to $1-10 \%$ of the experimental [Ca+Mg] (assumed totally as $\left[\mathrm{Mg}^{2+}\right]$ ) in $90 \%$ of these values; which indicates that the approximation $\left[\mathrm{Mg}^{2+}\right] \gg>\left[\mathrm{Ca}^{2+}\right]$ (necessary to operate the model) was reasonable in these systems that accumulate alkaline sodium salts and $\mathrm{CaCO}_{3}$. Excluding the 0.0-0.2 m depth, where the model had a bad performance, the main differences between experimental and predicted concentrations can be due to the fact that the $\mathrm{pH}$ was measured in saturation pastes, whereas experimental concentrations were measured in saturation extracts. 
Table 3 - Ion concentrations, pH and Gapon selectivity coefficients (KG) of the Pantanal soil, at 0.1 -m depth intervals, predicted by using the proposed model (equations from 20 to 24$)$ and experimental data from Table $1\left(\left[\mathrm{Mg}^{2+}\right]=[\mathrm{Ca}+\mathrm{Mg}]\right.$, $\mathrm{PCO}_{2}=0.35 \times 10^{-4} \mathrm{MPa}$ ).

\begin{tabular}{|c|c|c|c|c|c|c|}
\hline Depth & $\mathrm{Ca}^{2+}$ & $\mathrm{HCO}_{3}^{-}$ & $\mathrm{CO}_{3}{ }^{2-}$ & $\mathrm{HCO}_{3}+\mathrm{CO}_{3}^{2-}$ & $\mathrm{pH}$ & $K G$ \\
\hline -- m -- & 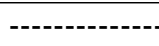 & ---------- & $-1 \quad \ldots-\cdots$ & - & & $\left(\mathrm{mmol} \mathrm{L}^{-1}\right)^{-1 / 2}$ \\
\hline $0.0-0.1$ & 0.33 & 2.46 & 0.13 & 2.59 & 8.63 & 0.01090 \\
\hline $0.1-0.2$ & 0.03 & 9.52 & 2.21 & 11.73 & 9.19 & 0.02565 \\
\hline $0.2-0.3$ & 0.03 & 9.32 & 2.04 & 11.36 & 9.19 & 0.05385 \\
\hline $0.3-0.4$ & 0.01 & 14.14 & 4.91 & 19.05 & 9.36 & 0.04436 \\
\hline $0.4-0.5$ & 0.02 & 12.25 & 3.55 & 15.80 & 9.31 & 0.13060 \\
\hline $0.5-0.6$ & 0.02 & 11.50 & 3.11 & 14.61 & 9.28 & 0.24711 \\
\hline $0.6-0.7$ & 0.01 & 14.03 & 4.78 & 18.81 & 9.36 & 0.08209 \\
\hline $0.7-0.8$ & 0.01 & 13.88 & 4.68 & 18.56 & 9.36 & 0.07454 \\
\hline $0.8-0.9$ & 0.02 & 13.31 & 4.28 & 17.59 & 9.34 & 0.07135 \\
\hline $0.9-1.0$ & 0.02 & 12.48 & 3.72 & 16.20 & 9.31 & 0.07462 \\
\hline $1.0-1.1$ & 0.03 & 9.51 & 2.10 & 11.61 & 9.20 & 0.08085 \\
\hline $1.1-1.2$ & 0.08 & 4.99 & 0.55 & 5.54 & 8.93 & 0.19897 \\
\hline $1.2-1.3$ & 0.02 & 10.07 & 2.35 & 12.42 & 9.23 & 0.09416 \\
\hline $1.3-1.4$ & 0.02 & 10.20 & 2.41 & 12.61 & 9.23 & 0.11834 \\
\hline $1.4-1.5$ & 0.03 & 8.91 & 1.82 & 10.73 & 9.18 & 0.13685 \\
\hline $1.5-1.6$ & 0.04 & 7.19 & 1.16 & 8.35 & 9.09 & 0.12673 \\
\hline $1.6-1.7$ & 0.02 & 10.34 & 2.49 & 12.83 & 9.24 & 0.06205 \\
\hline $1.7-1.8$ & 0.02 & 11.02 & 2.84 & 13.86 & 9.26 & 0.07258 \\
\hline $1.8-1.9$ & 0.02 & 9.83 & 2.23 & 12.06 & 9.22 & 0.08447 \\
\hline $1.9-2.0$ & 0.04 & 7.65 & 1.32 & 8.97 & 9.11 & 0.06086 \\
\hline 2.0-2.1 & 0.03 & 9.39 & 2.02 & 11.41 & 9.20 & 0.06838 \\
\hline 2.1-2.2 & 0.03 & 8.94 & 1.83 & 10.77 & 9.18 & 0.05897 \\
\hline 2.2-2.3 & 0.03 & 8.93 & 1.83 & 10.76 & 9.18 & 0.05255 \\
\hline 2.3-2.4 & 0.03 & 8.83 & 1.78 & 10.61 & 9.17 & 0.06812 \\
\hline 2.4-2.5 & 0.02 & 9.75 & 2.19 & 11.94 & 9.22 & 0.06214 \\
\hline
\end{tabular}

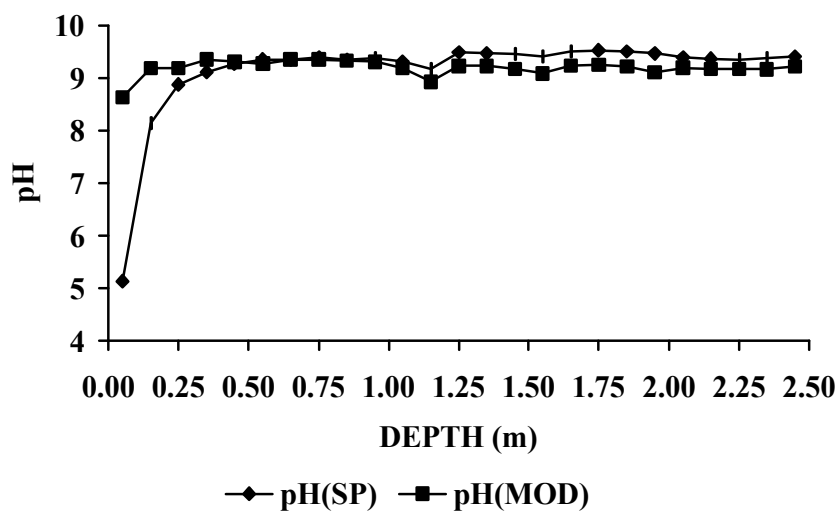

Figure 2 - Experimental pH values measured in saturation paste (SP) and $\mathrm{pH}$ values predicted by using the proposed model (MOD) [equations from 20 to 24], at $0.1 \mathrm{~m}$ depth intervals, in the Pantanal soil.

On the other hand, for predicting the $\mathrm{pH}$ and concentration values shown in Figures 2 and 3, the model with the best performance (using equations from 20 to 24) generates KG values (Table 3) between 2 and 17 times greater than $0.01475\left(\mathrm{mmol} \mathrm{L}^{-1}\right)^{-1 / 2}$; except for 0.0 $0.1 \mathrm{~m}$ depth where is comparable to this value. These $K G$ values are identical, until the fourth decimal figure, to the KG values (not reported here) calculated by using the experimental values of ESP, $\left[\mathrm{Na}^{+}\right]$and $[\mathrm{Ca}+\mathrm{Mg}]$ (Table 1) in equation 14. Bohn et al. (1979) indicated that the Gapon equation, with a KG value of 0.01475

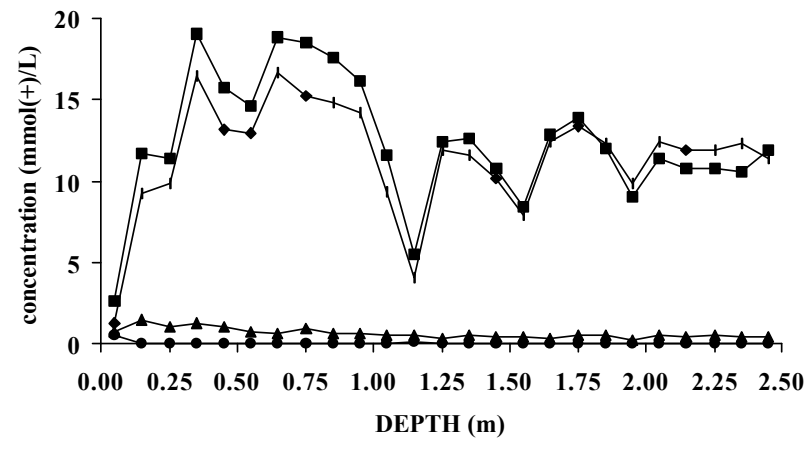

$$
\begin{aligned}
& \rightarrow \mathrm{HCO3}+\mathrm{CO} 3(\mathrm{SP}) \rightarrow-\mathrm{HCO}+\mathrm{CO} 3(\mathrm{MOD}) \\
& \rightarrow \mathrm{Ca}+\mathrm{Mg} \text { (SP) } \rightarrow \mathrm{Ca} \text { (MOD) }
\end{aligned}
$$

Figure 3 - Concentrations of $\mathrm{HCO}_{3}{ }^{-}+\mathrm{CO}_{3}{ }^{2-}, \mathrm{Ca}^{2+}+\mathrm{Mg}^{2+}$ and $\mathrm{Ca}^{2+}$ in the Pantanal soil, at $0.1 \mathrm{~m}$ depth intervals, measured in saturation paste (SP) and predicted by using the proposed model (MOD) [equations from 20 to 24].

$\left(\mathrm{mmol} \mathrm{L}^{-1}\right)^{-1 / 2}$, cannot be satisfactorily applied for soils when ESP values are above $40 \%$. All ESPs for the Pantanal soil, except at a 0.0-0.1 m depth, are higher than $40 \%$ (Table 1). These high ESP values are associated with both relatively high quantities of alkaline sodium salts (expressed as $\left[\mathrm{HCO}_{3}{ }^{-}\right]+\left[\mathrm{CO}_{3}{ }^{2}\right]-[\mathrm{Ca}+\mathrm{Mg}]$ ) and very low $[\mathrm{Ca}+\mathrm{Mg}]$ in solution (Table 1). Under these conditions, a poor competition of divalent ions for the exchange sites can be expected and also a progressive sodification of the exchanger phase. The KG values obtained in conditions where alkaline sodium salts in 
solution are present reflect a greater preference of the soil for sodium ion. Therefore, the high-predicted KG in the Pantanal soil could be due to the high accumulation of alkaline sodium salts.

Table 4 shows for different depths in the Pantanal soil, both predicted ion concentrations and partial pressures of $\mathrm{CO}_{2}$ by using the proposed model (equations from 20 to 24) and forced to adjust simultaneously the experimental data for $\left[\mathrm{Na}^{+}\right]$and $\mathrm{pH}$ in Table 1. In the shallow horizon (0.0-0.1 m), the misleading $\mathrm{CO}_{2}$ pressure calculated for the model clearly indicates no equilibrium with the calcite phase. A value of $\mathrm{CO}_{2}$ partial pressure of $4.90 \times 10^{-4} \mathrm{MPa}, 14$ times greater than the atmospheric $\mathrm{CO}_{2}$ partial pressure $\left(0.35 \times 10^{-4} \mathrm{MPa}\right)$, was calculated in the sample that corresponded to 0.1 $0.2 \mathrm{~m}$ depth. This fact seems to indicate some microbiological activity in that sample, probably due to a relatively high content of organic matter. Important discrepancies were also obtained between predicted [Ca] and $\left[\mathrm{HCO}_{3}{ }^{-}\right]+\left[\mathrm{CO}_{3}{ }^{2}\right]$ determined to $\mathrm{CO}_{2}$ partial pressure of $4.90 \times 10^{-4} \mathrm{MPa}$ and those calculated considering a $\mathrm{CO}_{2}$ partial pressure of $0.35 \times 10^{-4} \mathrm{MPa}$. For this reason, the assumption that the $\mathrm{CO}_{2}$ partial pressure is atmospheric could be not very realistic for a saturation paste if it contains high quantities of organic matter.

Moreover, below 0.2-m depth, where this degraded soil has presumably very low quantities of organic matter, the $\mathrm{CO}_{2}$ partial pressures had been calculated to be between 0.4 and 2.3 times the atmospheric $\mathrm{CO}_{2}$ partial pressure (Table 4). In these cases, the differences in $\left[\mathrm{Ca}^{2+}\right]$ and $\left[\mathrm{HCO}_{3}{ }^{-}\right]+\left[\mathrm{CO}_{3}{ }^{2-}\right]$ obtained as a function of their respective $\mathrm{CO}_{2}$ partial pressures (Table 4) and those calculated assuming a $P$ of $0.35 \times 10^{-4} \mathrm{MPa}$ (Table 3 ) were, respectively, between 0 and $0.03 \mathrm{mmol}_{\mathrm{c+}} \mathrm{L}^{-1}$ and between 0 and $0.04 \mathrm{mmol}_{\mathrm{c+}} \mathrm{L}^{-1}$. For this reason, when the quantity of organic matter in the sample is low, the assumption that the $\mathrm{CO}_{2}$ partial pressure is atmospheric can produce realistic results for a saturation paste as it is reacted with water.

Results obtained by our model for a system that accumulates alkaline sodium salts and $\mathrm{CaCO}_{3}$, with a hypothetical KG of $0.01475\left(\mathrm{mmol} \mathrm{L}^{-1}\right)^{-1 / 2}$, show that all $\mathrm{pH}$ values were above 8.3 (Tables 5 and 6 ). Sodium salts undergoing alkaline hydrolysis (expressed as $\left.\left[\mathrm{HCO}_{3}{ }^{-}\right]+\left[\mathrm{CO}_{3}{ }^{2-}\right]-[\mathrm{Ca}+\mathrm{Mg}]\right)$ and $\mathrm{pH}$ values were enhanced by increasing ESP; but the values were higher at $\left[\mathrm{SO}_{4}{ }^{2}\right]=1 \mathrm{mmol}_{\text {c+ }} \mathrm{L}^{-1}$ (relatively low ionic strength, Table 5) as compared with the $\left[\mathrm{SO}_{4}{ }^{2}\right]>1 \mathrm{mmol}_{\mathrm{ct}} \mathrm{L}^{-1}$ (Table 6). High $\mathrm{pH}$ values are possible in soils that accumulate alkaline sodium salts (bicarbonates and carbonates) and $\mathrm{CaCO}_{3}$, even in soils with relatively low ionic strength, without considering the hypothesis of the "hydrolysis of exchangeable sodium".

Tables 5 and 6 show an inversion in the $\left[\mathrm{HCO}_{3}\right] /$ $\left[\mathrm{CO}_{3}^{2}\right]$ ratio (values of less than 1 ) at ESP values above $60 \%$. These results could be used as a partial explanation of the genesis of sodic soils. The following reactions are proposed to represent the dominant processes of sodification in soils as a function of ESP:

$$
\begin{aligned}
& 2 \mathrm{NaHCO}_{3}+\mathrm{CaX}_{2} \longrightarrow 2 \mathrm{NaX}+\mathrm{CaCO}_{3}+\mathrm{CO}_{2}+ \\
& \mathrm{H}_{2} \mathrm{O}(\mathrm{ESP}<60 \%)
\end{aligned}
$$

$\mathrm{Na}_{2} \mathrm{CO}_{3}+\mathrm{CaX}_{2} \longrightarrow 2 \mathrm{NaX}+\mathrm{CaCO}_{3}(\mathrm{ESP}>60 \%)$

According to reaction (25), at ESP values between $10 \%$ and $60 \%$, an accumulation of sodium bicarbonate, and production of $\mathrm{CO}_{2}$ and $\mathrm{CaCO}_{3}$ would characterize the sodification process. Consequently, relatively lower $\mathrm{pH}$ values would be obtained. On the other hand, reaction (26) shows that $\mathrm{Na}_{2} \mathrm{CO}_{3}$ would dominate in the soil solution at ESPs higher than $60 \%$, and $\mathrm{pH}$ could reach values of 10 and even higher. Both reactions point out that the accumulation of alkaline sodium salts in soils cause the increase of exchangeable sodium and the production of $\mathrm{CaCO}_{3}$. Both processes have been reported in alkali sodic soils (Gupta et al., 1985; Pla-Sentís, 1985; Gupta \& Abrol, 1990; Guerrero-Alves, 1998).

Table 4 - Ion concentrations and partial pressures of $\mathrm{CO}_{2}(P)$ in the Pantanal soil, at $0.1 \mathrm{~m}$ depth intervals, predicted by using the proposed model (equations from 20 to 24) and forced to adjust simultaneously the experimental data for $\left[\mathrm{Na}^{+}\right]$

\begin{tabular}{|c|c|c|c|c|c|}
\hline \multirow{2}{*}{$\begin{array}{l}\text { Depth } \\
--m--\end{array}$} & \multirow{2}{*}{\multicolumn{4}{|c|}{$\mathrm{Ca}^{2+} \mathrm{HCO}_{3}^{-} \mathrm{CO}_{3}^{2-} \mathrm{HCO}_{3}^{-}+\mathrm{CO}_{3}^{2-}$}} & \multirow{2}{*}{$\frac{\left(P \times 10^{4}\right)}{\mathrm{MPa}}$} \\
\hline & & & & & \\
\hline $0.0-0.1$ & 72.61 & 74.89 & 0.00 & 74.89 & 29000.00 \\
\hline $0.1-0.2$ & 0.28 & 11.76 & 0.24 & 12.00 & 4.90 \\
\hline $0.2-0.3$ & 0.05 & 10.31 & 1.09 & 11.40 & 0.80 \\
\hline $0.3-0.4$ & 0.02 & 15.95 & 3.11 & 19.06 & 0.70 \\
\hline $0.4-0.5$ & 0.02 & 12.43 & 3.36 & 15.79 & 0.38 \\
\hline $0.5-0.6$ & 0.02 & 11.03 & 3.58 & 14.61 & 0.28 \\
\hline $0.6-0.7$ & 0.01 & 14.11 & 4.70 & 18.81 & 0.36 \\
\hline $0.7-0.8$ & 0.01 & 13.53 & 5.02 & 18.55 & 0.31 \\
\hline $0.8-0.9$ & 0.02 & 13.24 & 4.35 & 17.59 & 0.34 \\
\hline $0.9-1.0$ & 0.02 & 12.02 & 4.17 & 16.19 & 0.29 \\
\hline $1.0-1.1$ & 0.02 & 9.04 & 2.56 & 11.60 & 0.26 \\
\hline $1.1-1.2$ & 0.05 & 4.61 & 0.89 & 5.50 & 0.19 \\
\hline 1.2-1.3 & 0.01 & 8.62 & 3.78 & 12.40 & 0.16 \\
\hline 1.3-1.4 & 0.02 & 8.96 & 3.63 & 12.59 & 0.18 \\
\hline $1.4-1.5$ & 0.02 & 7.66 & 3.04 & 10.70 & 0.16 \\
\hline $1.5-1.6$ & 0.02 & 6.17 & 2.15 & 8.32 & 0.14 \\
\hline $1.6-1.7$ & 0.01 & 8.83 & 3.98 & 12.81 & 0.16 \\
\hline $1.7-1.8$ & 0.01 & 9.34 & 4.49 & 13.83 & 0.16 \\
\hline $1.8-1.9$ & 0.02 & 8.30 & 3.73 & 12.03 & 0.15 \\
\hline $1.9-2.0$ & 0.02 & 6.42 & 2.52 & 8.94 & 0.13 \\
\hline $2.0-2.1$ & 0.02 & 8.53 & 2.86 & 11.39 & 0.21 \\
\hline $2.1-2.2$ & 0.02 & 8.15 & 2.60 & 10.75 & 0.21 \\
\hline 2.2-2.3 & 0.02 & 8.26 & 2.49 & 10.75 & 0.22 \\
\hline 2.3-2.4 & 0.02 & 7.98 & 2.62 & 10.60 & 0.20 \\
\hline 2.4-2.5 & 0.02 & 8.79 & 3.13 & 11.92 & 0.20 \\
\hline
\end{tabular}
and $\mathrm{pH}$ in Table 1.

Note: Gapon selectivity coefficients $(\mathrm{kg})$ were also calculated in Table 4. Their values are indentical to $\mathrm{kg}$ values reported in Table 3. 
Table 5 - Constituents of $\mathrm{Na}_{2} \mathrm{CO}_{3}\left(\mathrm{NaHCO}_{3}\right)-\mathrm{CaCO}_{3}-\mathrm{CO}_{2}-$ exchanger system, for different exchangeable sodium percentages (ESP), obtained from the application of the proposed model (equations from 20 to 24): $\mathrm{PCO}_{2}=0.35 \times 10^{-4} \mathrm{MPa}, \mathrm{KG}=$ $0.01475\left(\mathrm{mmol} \mathrm{L}^{-1}\right)^{-1 / 2},\left[\mathrm{Cl}^{-}\right]=4 \mathrm{mmol}_{\mathrm{C}^{+}} \mathrm{L}^{-1}$, $\left[\mathrm{SO}_{4}^{2-}\right]=\left[\mathrm{Mg}^{2+}\right]=1 \mathrm{mmol} \mathrm{L}^{-1}$.

\begin{tabular}{lrrrrrr}
\hline ESP & {$\left[\mathrm{HCO}_{3}{ }^{-}\right]$} & {$\left[\mathrm{CO}_{3}{ }^{2-}\right]$} & {$\left[\mathrm{Na}^{+}\right]$} & {$\left[\mathrm{Ca}^{2+}\right]$} & $\mathrm{B} / \mathrm{C}^{*}$ & $\mathrm{pH}$ \\
\hline$\%$ & $---------\mathrm{mmol}_{\mathrm{C+}} \mathrm{L}^{-1}$ & ---------- & \\
10 & 1.83 & 0.07 & 5.33 & 0.58 & 25.40 & 8.50 \\
20 & 6.93 & 1.09 & 11.98 & 0.05 & 6.37 & 9.07 \\
30 & 12.69 & 3.85 & 20.55 & 0.02 & 3.30 & 9.32 \\
40 & 18.91 & 9.02 & 31.96 & 0.01 & 2.10 & 9.48 \\
50 & 25.94 & 17.96 & 47.94 & 0.01 & 1.44 & 9.61 \\
60 & 34.31 & 33.53 & 71.91 & 0.00 & 1.02 & 9.72 \\
70 & 45.11 & 62.66 & 111.86 & 0.00 & 0.72 & 9.82 \\
80 & 60.78 & 126.85 & 191.76 & 0.00 & 0.48 & 9.94 \\
90 & 89.34 & 337.90 & 431.45 & 0.00 & 0.26 & 10.11 \\
\hline
\end{tabular}

${ }^{*} \mathrm{~B} / \mathrm{C}=\left[\mathrm{HCO}_{3}^{-}\right] /\left[\mathrm{CO}_{3}{ }^{2-}\right]$

Table 6 - Constituents of $\mathrm{Na}_{2} \mathrm{CO}_{3}\left(\mathrm{NaHCO}_{3}\right)-\mathrm{CaCO}_{3}-\mathrm{CO}_{2}-$ exchanger system, for different exchangeable sodium percentages (ESP), obtained from the application of the proposed model (equations from 20 to 24): $\mathrm{PCO}_{2}=0.35 \times 10^{-4} \mathrm{MPa}, \mathrm{KG}=$ $0.01475\left(\mathrm{mmol} \mathrm{L}^{-1}\right)^{-1 / 2},[\mathrm{Cl}]=4 \mathrm{mmol}^{++} \mathrm{L}^{-1},\left[\mathrm{Mg}^{2+}\right]$ $=1 \mathrm{mmol}^{-1} \mathrm{~L}^{-1}$.

\begin{tabular}{|c|c|c|c|c|c|c|c|}
\hline ESP & $\left.\mathrm{HCO}_{3}^{-}\right]$ & {$\left[\mathrm{CO}_{3}^{2-}\right]$} & {$\left[\mathrm{SO}_{4}^{2-}\right]$} & {$\left[\mathrm{Na}^{+}\right]$} & {$\left[\mathrm{Ca}^{2+}\right]$} & $\mathrm{B} / \mathrm{C}^{*}$ & $\mathrm{pH}$ \\
\hline$\%$ & \multicolumn{7}{|c|}{----------------- $\mathrm{mmol}_{\mathrm{c}+} \mathrm{L}^{-1}$---------------- } \\
\hline 10 & 1.36 & 0.04 & 2.00 & 5.33 & 1.08 & 33.73 & 8.37 \\
\hline 20 & 4.60 & 0.48 & 4.00 & 11.98 & 0.11 & 9.52 & O \\
\hline 30 & 9.42 & 2.14 & 6.00 & 20. & 0.03 & 41 & 9.1 \\
\hline 40 & 15.13 & 5.81 & 8.0 & 31 & 0.01 & 2.61 & 9.3 \\
\hline 50 & 96 & 12.94 & .00 & 47.94 & 0.01 & 1.70 & 9.5 \\
\hline 60 & 30.42 & 26.43 & 12.00 & 71.91 & 0.00 & 1.15 & 9.6 \\
\hline 70 & 41.53 & 53.24 & 14.00 & 111.86 & 0.00 & 0.78 & 9.7 \\
\hline 80 & 57.79 & 114.84 & 16.00 & 191.76 & 0.00 & 0.50 & 9.92 \\
\hline 90 & 87.31 & 322.93 & 18.00 & 431.45 & 0.00 & 0.27 & 10.10 \\
\hline
\end{tabular}

${ }^{*} \mathrm{~B} / \mathrm{C}=\left[\mathrm{HCO}_{3}^{-}\right] /\left[\mathrm{CO}_{3}^{2-}\right]$

For $\mathrm{ESP}>40 \%$, the predicted concentration of alkaline sodium salts $\left(\left[\mathrm{HCO}_{3}{ }^{-}\right]+\left[\mathrm{CO}_{3}{ }^{2}\right]-[\mathrm{Ca}+\mathrm{Mg}]\right)$ [Tables 5 and 6] are considerably higher than the experimental concentrations of alkaline sodium salts in the Pantanal soil (Table 1). However, these predicted values were considerably lower than the solubilities of sodium carbonate $\left(4038 \mathrm{mmol} \mathrm{L}^{-1}\right)$ and bicarbonate $(1143 \mathrm{mmol}$ $\mathrm{L}^{-1}$ ) in pure water (Welcher \& Hahn, 1969). In these simulations, increasing $K G$ to values higher than $0.01475\left(\mathrm{mmol} \mathrm{L}^{-1}\right)^{-1 / 2}$ (no reported here), it was possible to obtain lower concentrations of alkaline sodium salts and $\mathrm{pH}$ for a given ESP. According to our simulation model, an exchanger of ions seems to cause a depressive effect on solubilities of alkaline sodium salts, especially at low ESP and KG>0.01475 $\left(\mathrm{mmol} \mathrm{L}^{-1}\right)^{-1 / 2}$. Therefore, under these conditions, sodium carbonate and bicarbonate would be less soluble in the soil solution than in pure water. However, the solubilities increase at higher ESP values, resulting in higher $\mathrm{pH}$ values. From this, it appears that KG values of 0.01475 $\left(\mathrm{mmol} \mathrm{L}^{-1}\right)^{-1 / 2}$, used to generate our data in Tables 5 and 6 , could not be adequate to simulate the behavior of the alkali sodic soil Pantanal under conditions of low ionic strength and high ESP.

\section{CONCLUSIONS}

$K G$ values determined by our model seem to show a high selectivity of the Pantanal soil for the sodium ion. This could be due to the fact that the accumulation of alkaline sodium salts severely restricts the presence of divalent cations in solution, which are mainly precipitated as calcium carbonates. KG values obtained for the Pantanal soil and the results obtained in the simulation of the hypothetical system are suggesting that a KG value higher than $0.01475\left(\mathrm{mmol} \mathrm{L}^{-1}\right)^{-1 / 2}$ should be used to adequately simulate the behavior of the Pantanal soil at low ionic strength and high ESP values.

\section{REFERENCES}

BOHN, H.L; MCNEAL, B.L.; O'CONNOR, G.E. Soil chemistry. New York: John Wiley \& Sons, 1979. 329p.

BROWN, D.S; MILLER, R.J. Bentonite instability and its influence on activation energy measurements. Proceedings of Soil Science Society of America, v.35, p.705-710, 1971.

CRUZ-ROMERO, G.; COLEMAN, N.T. Reactions responsible for high pH of Nasaturated soils and clays. Journal of Soil Science, v.26, p.169-175, 1975.

GUERRERO-ALVES, J. Génesis de suelos sódicos en diferentes ambientes edafoclimáticos de Venezuela. Maracay, 1998. 237p. Tesis (Doctoral) Facultad de Agronomía, Universidad Central de Venezuela.

GUPTA, R.K.; SINGH, C.P.; ABROL, I.P. Determining cation exchange capacity and exchangeable sodium in alkali soils. Soil Science, v.139, p.326-332, 1985.

GUPTA, R.K.; ABROL, I.P. Reclamation and management of alkali soils. Indian Journal of Agricultural Science, v.60, p.1-16, 1990.

KOVDA, V.A.; SAMOILOVA, E.M. Some problems of soda salinity. Agrokémia és Talajtan, v.18, p.21-36, 1969.

MASHHADY, A.S.; ROWELL, D.L. Soil alkalinity. I. Equilibria and alkalinity development. Journal of Soil Science, v.29, p.67-75, 1978.

NAKAYAMA, F.S. Hydrolysis of $\mathrm{CaCO}_{3}, \mathrm{Na}_{2} \mathrm{CO}_{3}$ y $\mathrm{NaHCO}_{3}$ and their combinations in the presence and absence of external $\mathrm{CO}_{2}$ source. Soil Science, v.109, p.391-398, 1970.

PETERS, D.G.; HAYES, J.M.; HIEFTJE, G.M. Chemical separations and measurements: theory and practice of analytical chemistry. Philadelphia: W.B. Saunders, 1974. $749 p$.

PLA SENTÍS, I. Metodología de laboratorio recomendada para el diagnóstico de salinidad y alcalinidad en suelos, aguas, y plantas. Maracay: Universidad Central de Venezuela, Facultad de Agronomía, Instituto de Edafología, 1969. 103p.

PLA SENTíS, I. Origen, distribución y diagnóstico de suelos afectados por sales en Venezuela. Revista de la Facultad de Agronomía, v.14, p.125-150, 1985.

PORTA, J.; LÓPEZ-ACEVEDO, M.; ROQUERO, C. Edafología: para la agricultura y el medio ambiente. Madrid: Ediciones Mundi-Prensa, 1999. 849p.

ROBBINS, C.W. Sample preparation for determining ions in dark colored sodic soil extracts. Soil Science Society of America Journal, v.53, p.721-725, 1989.

SHAINBERG, I. Rate and mechanism of Na-montmorillonite hydrolysis in suspensions. Proceedings of Soil Science Society of America, v.37, p.689-694, 1973.

SKOOG, D.A.; WEST, D.M. Análisis instrumental. México: Nueva Editorial Interamericana, 1975. 718p.

SOIL SURVEY STAFF. Keys to soil taxonomy. Washington: USDA, Natural Resources Conservation Service, 1998. 326p.

SZABOLCS, I. The influence of sodium carbonate on soil forming processes and soil properties. Agrokémia és Talajtan, v.18, p.37-68, 1969.

SZABOLCS, I. The global problems of salt-affected soils. Acta Agronomica Hungarica, v.36, p.159-172, 1987

UNITED STATES SALINITY LABORATORY STAFF. Diagnosis and improvement of saline and alkali soils. Washington: USDA, 1954. (Agriculture Handbook, 60).

WELCHER, F.J.; HAHN, R.B. Semimicro qualitative analysis. New York: Van Nostrand Reinhold, 1969. 497p.

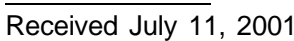

